\title{
QUANTITATIVE SEMIMICRO INORGANIC PROCEDURES by
}

\author{
CHARLES L. RULFS
}

Dept. of Chemistry, University of nfichigan, Ann Arbor (U.S.A.)

\section{INTRODUCTION}

The wide popularity of micro and semimicro quantitative organic procedures is undoubtedly to be attributed to their timesaving features more than to any justification based on limited availability of sample; this factor has been well discussed by HALLETT. With respect to all typical analytical operations with the possible exception of weighing (dissolution of the sample, evaporations, filtration and washing, drying or ignition, etc.) the same favorable time eomparisons would seem to apply to inorganic procedures. The approximate figures recorded in Table I emphasize this point. Reduced-scale techniques, however, have only been applied te inorganic procedures in relatively isolated instances.

TABLE I

MACRO VS. MICRO TIME-REQUIREMENTS FOR TYPICAL ANALYTICAL OPERATIONS

\begin{tabular}{|c|c|c|}
\hline \multirow{2}{*}{ - Operation } & \multicolumn{2}{|c|}{ Time required, $\mathrm{min}$} \\
\hline & Macro & Micro \\
\hline $\begin{array}{l}\text { Solution or fusion } \\
\text { Bringing a liquid to b.p. } \\
\text { Evaporation to dryness } \\
\text { Filtration and washing } \\
\text { Drying or ignition of pp'tt. } \\
\text { Cooling prior to weighing } \\
\text { Electrodeposition }\end{array}$ & $\begin{array}{l}30 \\
20 \\
70 \\
45 \\
60 \\
50 \\
80\end{array}$ & $\begin{aligned} & 12 \\
& 2(2 \mathrm{nll}) \\
& 10 \\
& 10 \\
& 15 \\
& 25 \\
& 30\end{aligned}$ \\
\hline
\end{tabular}

This discrepancy in practice appears to rest in large part on a rather fundamental difference between organic and inorganic analytical problems; whereas both macro and micro organic procedure tends to fall in the "unitoperations" category, "multiple-operations" involving six or more samples are conventional in inorganic practice. Accordingly, while the microchemist may well boast that his micro-drying-block will dry a precipitate in only 15 minutes Roferences P. 54 . 
whereas 30 to 40 minutes are required in a conventional drying oven, it is also true that six samples would require six times ${ }^{5}$ minutes of his time against only 35 minutes with a drying oven. Nor does his salvation lie in obtaining six dryingblocks, since it would require much more than 15 min utes to place six microbeakers and filtersticks into position, adjust the temperature of each block, regulate the suction devices, etc.

The situation just noted applies as well to other operations. Thus, while a single "filter-paper and funnel" macro filtration is a rather slow and inefficient process, very little additional time is involved when a rack of six funnels is handled at one time. Hence the situation evidenced in Table $I$, which is based upon a single sample, no longer holds true when two or more samples are considered. Taking the time for a single-sample microdetermination as unity, a rough comparison of the time-requirements for macro $v s$. micro practice as a function of the number of

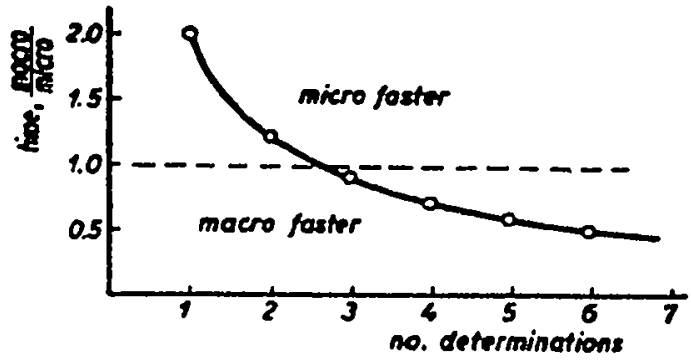

Fig. $x$. Relative time required ior macro vs. micro inorganic analyses as a function of the number of samples processed at one time. Based upon a single microdetermination as unity samples handled is presented graphically in Fig. I. The figures employed in devising this graph are exclusive of weighing-time and are based on typical gravimetric procedures (volumetric and electrolytic procedures show the same trends but not as markedly). In general, one may conclude that two or more samples may be handled as efficiently by macro- as by microscale techniques.

Much time, unfortunately, has been devoted to devising microapparatus which will accommodate a single determination. Water baths, filter assemblies, drying devices, etc., are more ofter than not designed to hold a single micro beaker (see, e.g., the excellent and extensive descriptions of microanalytical ware in p. 4 to 145 of HECHT AND DONA ${ }^{2}{ }^{2}$. Practical inorganic work involving six or more samples is nevertheless possible employing a semimicro scale and enjoying an appreciable saving of time over macro practice. Selected gravimetric, volumetric, and electrolytic procedures using samples of 23 to 62 mg are discussed from the standpoint of time-required and accuracy-obtained.

\section{EXPERIMENTAL}

All weighings were performed on an Ainsworth keyboard type TCX semimicro balance. Weights were recorded to the nearest $0.005 \mathrm{mg}$, and the reproducibility of the balance using this practice was found to be plus or minus o.or $\mathrm{mg}$. The "flannel and chamois" wiping technique was not employed in the case of the Relerences p. 54 . 
one low-temperature drying form used: its omission, however, results in only a small saving in time since its inclusion somewhat shortens the time required for cooling prior to weighing (see, e.g., p. I92 BENEDETII-PICrIER ${ }^{3}$ ). Earlier experiments by the author using glass vessels of 7 to 8 grams mass and a microanalytical balance, indicate that a weight-reproducibility of between 0.008 and $0.0 \mathrm{rI} \mathrm{mg}$ is attainable without employing the wiping technique provided that a dryingtemperature reproducibility of plus or minus $5^{\circ} \mathrm{C}$ is main tained. The simplification is therefore justified for most semimicro work.

Electrolyses were conducted in the CIARK AND HERMANCE cell`employing air stirring and a conventional power source. Since only two cells and two pair of electrodes were available, only two electrodepositions could be conducted at one time. This situation, however, does not differ from the custom in macropractice except for rather special installations.

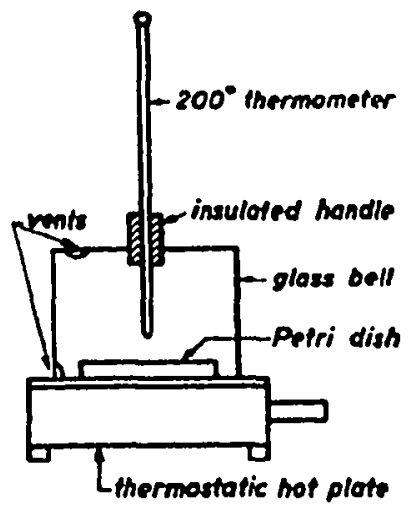

Fig. 2. Fisher Micro Dome Oven. A thermostatic hot-plate regulates the temperature of a small glass-enclosed chamber

Six or eight small vessels may be dried very conveniently in the compact hot-plate type of oven (Fisher Micro Dome Oven), consisting of a thermostatically controlled hot-plate bearing a glass shelf and larger glass cover (Fig. 2). The availability of several such devices in the laboratory will permit concurrent work - with determinative forms requiring a variety of drying temperatures.

Ignitions were conducted in a small muftle furnace (Temco Model GRP) using porcelain ignition capsules to seat the crucibles. The employment of a "small" muffle has the particular virtue that the requisite temperatures are more quickly attained.

0.05000 normal potassium bichromate solution was made up and used at $25^{\circ} \mathrm{C}$. Calibrated burets of Io $\times 0.02$ or $5 \times 0.0 \mathrm{Iml}$ capacity were used. A silver reductor of reduced size was found convenient (Fig. 3 ).

For convenience, samples for the two gravimetric determinations were dispensed by gravimetric-aliquoting of a standard solution of known weight-percent composition. This could be done with sufficient accuracy by weighing to the nearest $0.5 \mathrm{mg}$ on a conventional analytical balance.

\section{VOLUMETRIC IRON}

The direct determination of iron after reduction in $10 \%$ Roferonces p. 54 .

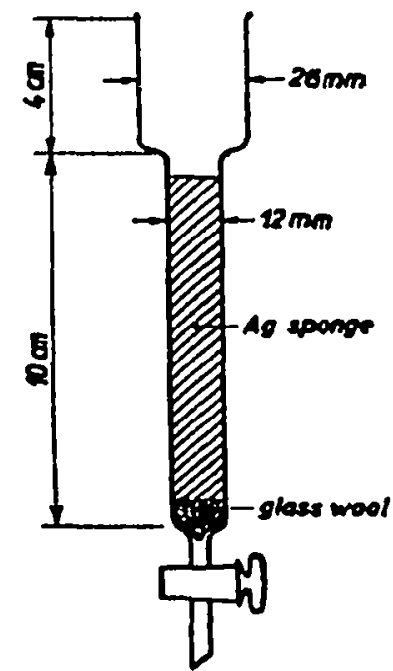

Fig. 3. Small silver reductor. Dimensioned for semimicro work with 5 to $20 \mathrm{ml}$ volumes of solutions. 
hydrochloric acid with the silver reductor ${ }^{5}$ and using a mild oxidant such as bichromate is a particularly selective procedure. Molybdenum is the only common interference, and must be removed prior to the reduction by acid-sulfide precipitation or other means.

\section{Procedure}

A sample of 20 to $70 \mathrm{mg}$ is weighed into a clean $8 \mathrm{ml}$ platinum crucible and treated with 0.5 to $0.6 \mathrm{ml}$ of conc. hydrochloric acid and 6 or 7 drops of hydrofluoric acid. The mass is warmed gently until it is reduced to $c .0 . x$ ml volume. If dissolution of the sample appears to progress satisfactorily with this treatnient, $2 \mathrm{ml}$ of $\mathrm{I}: \mathrm{I}$ hydrochloric acid are added and the solution is transferred to a 30 or $50 \mathrm{ml}$ beaker while washing generously and diluting finally to $10 \mathrm{ml}$ volume. If the sample is incompletely attacked with acids, the mass is taken to dryness, $0.5 \mathrm{~g}$ of anhjrdrous sodium carbonate is added, and the whole fused to a clear mclt. The cooled crucible is treated in a covered $100 \mathrm{ml}$ beaker with 8-10 ml of hot water, adding conc. hydrochloric acid dropwise until the mass is dissolved and the alkali neutralized. The crucible is rinsed and withdrawn, $3 \mathrm{ml}$ of $I: I$ hydrochloric acid are added to the beaker and the volume adjusted to $15 \mathrm{ml}$. Unless the reductor contains acid from a previous pas3, the following solutions are passed in order and collected in a $50 \mathrm{ml}$ Erlenmeyer flask; (excess water in reductor, discarded). $5 \mathrm{ml}$ of $10 \% \mathrm{HCl}$ the sample solution in $10 \% \mathrm{HCl}$, a $5 \mathrm{ml}$ rinse of the sample vessel with $10 \% \mathrm{HCl}$, a second $5 \mathrm{ml}$ rinse with $10 \% \mathrm{HCl}, 5 \mathrm{ml}$ additional of $\mathrm{HCl}$ to rinse the reductor, (Io to I $5 \mathrm{ml}$ of water to fill the reductor unless a succeeding determination follous immediately). Two $\mathrm{ml}$ of syrupy phosphoric acid and $\mathrm{I}$ drop of $0.2 \%$ sodium diphenylamine sulfonate indicator solution are added. The solution is titrated slowly with $0.05 N$ bichromate until near the end point, when an additional drop of indicatur solution is added.

TABLE II

SEMIMICRO VOLUMETRIC DETERMINATION OF IRON

\begin{tabular}{|c|c|c|c|}
\hline \multirow{2}{*}{ Material } & \multirow{2}{*}{ Sample mg } & \multicolumn{2}{|c|}{$\% \mathrm{Fe}$} \\
\hline & & Found & Theory \\
\hline Argillaceous & $\begin{array}{l}56.34 \\
51.09\end{array}$ & $\begin{array}{l}1.14 \\
1.13\end{array}$ & 1.14 \\
\hline 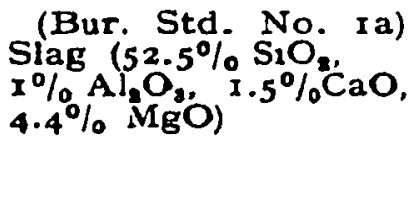 & $\begin{array}{l}23.06 \\
28.24 \\
25.11 \\
23.78 \\
24.83\end{array}$ & $\begin{array}{l}27.20 \\
27.52 \\
27.61 \\
27.46 \\
27.16\end{array}$ & $27 \cdot 35$ \\
\hline $\begin{array}{l}\text { Crescent Iron Ore } \\
\text { (Bur. Std. No. 26) }\end{array}$ & $\begin{array}{l}40.27 \\
38.86\end{array}$ & $\begin{array}{l}58.49 \\
58.65\end{array}$ & 58.62 \\
\hline $\begin{array}{l}\text { Sibley Iron Ore } \\
\text { (Bur. Std. No. 27b) }\end{array}$ & $\begin{array}{l}33 \cdot 76 \\
36 \cdot 35\end{array}$ & $\begin{array}{l}67.92 \\
68.15\end{array}$ & 68.23 \\
\hline $\begin{array}{l}\text { Magnetite Iron Orc } \\
\text { (Bur. Std. No. 29a) }\end{array}$ & $\begin{array}{l}35.12 \\
32.53 \\
34.71\end{array}$ & $\begin{array}{l}69.41 \\
69.50 \\
69.36\end{array}$ & 69.45 \\
\hline
\end{tabular}

References P. 54 . 
and the titration concluded. A gross blank-correction (for reagents, indicator, and reductor) of from 0.03 to $0.05 \mathrm{ml}$ was always found for the conditions cited. This, of course, should be individually established and will be slightly larger when the carbonate fusion is required.

Typical results by this procedure are given in Table II. A $5 \mathrm{ml}$ buret was used in the case of the first two samples. Fusion was employed in the case of the Crescent and the Sibley ores. The precision and accuracy of the technique can be seen to compare very favorably with macro practice. There is some justification for concluding that the inferior precision in the case of the sample labelled "slag" is due to poor sampling and heterogeneity (the material was ground only to 40-mesh size). Six acid-soluble sumples could be processed in seventy minutes inclusive of weighings.

\section{GRAVIMETRIC CHLORIDE AND ZINC}

The standard gravimetric procedures of chloride as the silver salt and zinc as the pyrophosphate were selected as common and typical cases for study. Attention was focused on the time required and precision obtained in the basic "determination" only, without regarl for preliminary separation techniques. Samples were taken from carefully standardized solutions of sodium chloride in $0 . x \%$ nitric acid and zinc sulfate in $1 \%$ sulfuric acid.

\section{Chloride Procedure}

A sample containing 2 to $20 \mathrm{mg}$ of chloride is dispensed into a 30 or a $50 \mathrm{ml}$ beaker and diluted to c. $20 \mathrm{ml}$ volume. $0.5 M$ silver nitrate is added dropwise, while swirling the solution, until an excess of 3 or 4 drops is present. The beakers are then warmed on the hot plate to near boiling, removed, and set aside for 1o or 15 minutes with occasional stirring. The precipitate is filtered with suction through a $1.5 \mathrm{ml}$ Gooch cricuble (Coors No. o) which has been tared after drying for $30 \mathrm{~min}$ at $150^{\circ} \mathrm{C}$. The transfer of the precipitate may be accomplished either by manual pouring or by a suction-filter-siphon which connects to the crucible tbrough a suitable one-hole rubber stopper (about the middle one-third of a No. o stopper). While the author agrees with the observation of INGRAM AND WATERS that the WINTERSTEINER transfer-assembly is unreliable, the simpler modification of a siphon-tube entering the crucible through a one-hole stopper seems to give little difficulty. The last traces of precipitate are transferred and washed with 6 or $8 \mathrm{ml}$ of $0.5 \%$ nitric acid (in smaller portions), employing a "feather" police-man if necessary, followed by 2 or $32-\mathrm{ml}$ portions of $10 \%$ alcohol. Suction is continued for several minutes after the final wash. The crucibles and their contents are then dried for c. 30 minutes on a hot plate oven. The crucibles are cooled in an aluminum de iccator (containing no desiccant) for $10-15 \mathrm{~min}$, and then on a metal cooling block alongside the balance for a further 8-ro minutes prior to weighing.

\section{Zinc Procodure}

The aciclic sample solution, contained in a $50 \mathrm{ml}$ beaker, is diluted to $25 \mathrm{ml}$ volume, treated with $\mathrm{I}-2$ drops of methyl red indicator and neutralized by dropwise addition of $1: 1$ ammonia using no more than $x-2$ drops excess. The beakers are transferred to a warm hot plate and the solutions treated with $10 \%$ diammonium hydrogen phosphate reagent. The reagent is added, dropwise, while stirring, to $0.2-0.3 \mathrm{ml}$ excess. The suspensions are warmed for 8 or $10 \mathrm{~min}$ with intermittent stirring. The beakers are then placed in a shallow bath containing cool water (a

References $p .54$. 
large crystallizing dish is convenient) and the precipitates are allowed to settle. Several drops of reagent are carefully added to each determination to check for completeness of precipitation. The determinations should stand for at least $20 \mathrm{mi}$ nutes with occasional stirring. Filter with suction through a tared (after drying at $1000^{\circ}$ C.) $8 \mathrm{ml}$ porcelain frit crucible (Royal Berlin No.0.9974 Az). Transfer by manual pouring using 15 to $20 \mathrm{ml}$ of cooled distilled water as a wash. The wash water is defivered from a graduated $50 \mathrm{ml}$ micro wash bottle and the volume used is noted. Several $\mathrm{ml}$ of $50 \%$ ethanol are used as a final wash (a few drops may well be applied earlier as an aid in transferring the last traces of precipitate). The frits are sucked as dry as possible, removed to porcelain ignition capsules and placed in the cold muffle. The muffle is turned on for fastest heat, and the crucibles may be removed as $800 \mathrm{n}$ as a temperature of $950-1000^{\circ} \mathrm{C}$ is attained (the entire process required about $25 \mathrm{~min}$ with the furnace used). Any deviations from this technique for adaption to otber types of apparatus must allow for (a) predrying at $110-160^{\circ}$ to avoid cracking the frits, (b) gradual increase of temperature beyond this point to prevent too vigorous an expulsion of ammonia and water, and (c) a final temperature of at least $900^{\circ}$ should be reached. The crucibles and capsules are first cooled from red heat on an open asbestos board (Transite) for c. $5 \mathrm{~min}$ before the crucibles (alone) are distributed on the clean porcelain plate in a sizeable descicator of conventional design (but which should contain either no desiccant or a very weak agent such as calcium chloride) for a cool.'. period of $15 \mathrm{~min}$. The crucibles are finally placed for to min on a metal block be le the balance before weighing. A solubility correction of $0.1 \mathrm{I} \mathrm{mg}$ per Io $\mathrm{ml}$ of vish water used is applied to each recorded weight of zinc pyrophosphate.

TABLE III

SEMIMICRO GRAVIMETRIC CHLORIDE AND ZINC

\begin{tabular}{|c|c|c|c|c|c|}
\hline \multicolumn{3}{|c|}{$\begin{array}{c}\text { Chloride as } \mathrm{AgCl} \\
\text { (Cl in } \mathrm{mg})\end{array}$} & \multicolumn{3}{|c|}{$\begin{array}{c}\mathrm{Zinc} \text { as } \mathrm{Z}_{n_{\mathbf{n}}} \mathrm{P}_{\mathbf{g}} \mathrm{O}_{2} \\
(\mathrm{Zn} \text { in } \mathrm{mg})\end{array}$} \\
\hline Taken & \multicolumn{2}{|c|}{ Found } & Taken & \multicolumn{2}{|c|}{ Found } \\
\hline 2.00 & \multicolumn{2}{|c|}{$\begin{array}{l}2.01 \\
2.00\end{array}$} & 2.09 & \multicolumn{2}{|c|}{$\begin{array}{l}2.10^{5} \\
2.09^{8}\end{array}$} \\
\hline 5.01 & $\begin{array}{l}5.01 \\
5.03\end{array}$ & $\begin{array}{l}5.02 \\
5.01\end{array}$ & $5.24^{8}$ & \multicolumn{2}{|c|}{$\begin{array}{l}5.25 \\
5.25\end{array}$} \\
\hline 10.02 & $\begin{array}{r}10.00 \\
9.99\end{array}$ & $\begin{array}{l}10.03 \\
10.01\end{array}$ & 10.49 & \multicolumn{2}{|c|}{$\begin{array}{l}10.48 \\
\times 0.50\end{array}$} \\
\hline 20.04 & \multicolumn{2}{|c|}{$\begin{array}{l}20.03 \\
20.07\end{array}$} & 20.98 & \multicolumn{2}{|c|}{$\begin{array}{l}20.97 \\
2 x .01\end{array}$} \\
\hline 25.05 & \multicolumn{2}{|c|}{$\begin{array}{l}25.04 \\
25.05\end{array}$} & 52.45 & $\begin{array}{l}52.43 \\
52.52\end{array}$ & $\begin{array}{l}52.37 \\
52.47\end{array}$ \\
\hline
\end{tabular}

The treatment of six chloride samples required about 60 minutes, while six zinc samples were processed in about 1 ro minutes inclusive of the digesting and cooling periods (which time, of course, may be used in part for other work). It is felt that these times represent a considerable improvement over the comparable case in macro work. The precision and accuracy of the results obtainable leave little to be desired as is evident from the data given in Table III.

Relerences p. 54. 


\section{ELECTROLYTIC COPPER}

Despite the absence of any favorable gravimetric fäctor, the electrodeposition of copper as the metal retains its popularity because of its simplicity, cleanliness, and rather good separation features (in a nitric acid medium). The only common in terferences are fairly readily removable, silver as the chloride and tin as metastannic acid. The latter is no longer so tedious since the introduction by CALEY AND BURFORD ${ }^{7}$ of the ammonium iodide volatilization technique, which not only gives reliable tin values but also expedites the necessary recovery of impurities for subsequent copper and lead determinations. The Pregl cell, which is prone to give low results with nitric acid media, is best replaced with the more convenient design of Ciark and Hermance. The air-stirring employed with the latter has the further advantage of permitting direct copper determinations on ferrous alloys as pointed out by MACNEVIN ANL BOURNIgUE ${ }^{8}$.

\section{Procedure}

The sample solution, which preferably contains at least $5 \mathrm{mg}$ and not more than 50-60 $\mathrm{mg}$ of copper, is transferred to the electrolytic cell and adjusted to 8-12 mi volume. In general, the free acidity of the final volume should either correspond to $3-4 \%$ nitric acid or to a mixture of $1-2 \%$ sulfuric acid plus $2 \%$ nitric acid (sulfuric acid is desirable as the initial solvent for many corrosion-resistant alloys, or it may be introduced in freeing the solution of chlorides by fuming). For details concerning the electrolyte composition with ferrous samples, the paper of MAcNevin AND BOURNIgUE should be consulted. About $20 \mathrm{mg}$ of urea is added and the electrodes, one of which has been tared, are initroduced. Either electrode can be used as the cathode but the larger outer-electrode is preferably used whenever $40 \mathrm{mg}$ or more of copper is to be plated. The bubbler tube is regulated to a reasonable rate of flow in an external vessel of water before introduction into the cell. The voltage is adjusted to $c .3 \mathrm{v}$. When no more copper color is evident in the solution (usually, within 1o to 15 minutes), the air-tube and cell wall are rinsed down with $0.8-1.2 \mathrm{mi}$ of water. After $5 \mathrm{~min}$ the upper portions are again rinsed and the electrolysis is continued for another $5 \mathrm{~min}$. At the end of this time the most recently wetted portion of the electrode leads is inspected for discoloration; if no copper deposition has occurred on this area, the run may be discontinued. The air-tube is carefully withdrawn (while rinsing, if the spent electrolyte is to be saved for further work). The bottom cock is opened slightly, allowing the electrolyte to drain into a convenient vessel, while washing generously from above with distilled water. As much as 40-50 $\mathrm{ml}$ may well be omployed for washing unless the electrolyte is required for further work. In any case, the electrodes must be completely covered with pure water before the current is broken; the plated electrode is then removed at once to an external container of distilled water. The electrode is then washed in ethanol followed by ether and dried for $5 \mathrm{~min}$ in an oven at c. 90-1 $10^{\circ} \mathrm{C}$. "Flaming off" the ether or warming directly over a burner should never be resorted to. Cooling for $5 \mathrm{~min}$, either suspended in air or resting on a metal cooling block, suffices. The electrode is then suspended from the central hook of the balance pan and the final weight taken after another $5 \mathrm{~min}$. Brass weights make satisfactory tares; but, in view of the long-range weight-constancy of platinum ware, it is convenient to prepare a permanent tare of heavy platinum wire for each electrode used.

Duplicate determinations could be completed in approximately 40 to 50 Reforcnces P. 54 . 
minutes, inclusive of weighings. The precision and accuracy for deposits weighing more than I $\mathrm{mg}$ were quite satisfactory as shown in Table IV.

TABLE IV

SEMIMICRO ELECTROLYTIC COPPER

\begin{tabular}{|c|c|c|c|c|}
\hline \multirow{2}{*}{ Material } & \multirow{2}{*}{$\begin{array}{l}\text { Sample. } \\
\text { mg }\end{array}$} & \multirow{2}{*}{$\underset{\text { Deposit. }}{\text { De }}$} & \multicolumn{2}{|c|}{$\% \mathrm{Cu}$} \\
\hline & & & Found & Theory \\
\hline $\begin{array}{l}\text { Cast Iron } \\
\text { (Bur. Std. No. 5r) }\end{array}$ & $\begin{array}{l}100 . x \\
108.0\end{array}$ & $\begin{array}{l}0.990 \\
1.060\end{array}$ & $\begin{array}{l}0.99 \\
0.98\end{array}$ & 1.00 \\
\hline $\begin{array}{l}\text { Zn Die Casting } \\
\text { (Bur. Std. No. 94a) }\end{array}$ & $\begin{array}{l}55.11 \\
61.25\end{array}$ & $\begin{array}{l}0.605 \\
0.660\end{array}$ & $\begin{array}{l}1.09 \\
1.08\end{array}$ & 1.08 \\
\hline $\begin{array}{l}\text { Cast Iron } \\
\text { (13ur. Std. No. II5) }\end{array}$ & $\begin{array}{l}35.62 \\
30.01\end{array}$ & $\begin{array}{l}2.295 \\
x .935\end{array}$ & $\begin{array}{l}6.46 \\
6.45\end{array}$ & 6.44 \\
\hline IK-Monel No. I & $\begin{array}{l}37.88 \\
44 \cdot 39\end{array}$ & $\begin{array}{l}10.77 \\
12.65\end{array}$ & $\begin{array}{l}28.4 \mathrm{I} \\
28.46\end{array}$ & 28.47 \\
\hline K-Monel No. 2 & $\begin{array}{l}50.41 \\
52.72\end{array}$ & $\begin{array}{l}\text { r } 5.01 \\
\text { r } 5.68\end{array}$ & $\begin{array}{l}29.78 \\
29.73\end{array}$ & 29.82 \\
\hline Std. Cu Sol'n. & ( $\mathrm{mg}$ of & copper) & $\begin{array}{l}40.12 \\
40.15\end{array}$ & 40.14 \\
\hline Std. Cu Sol'n. & ( $\mathrm{mg}$ of & copper) & $\begin{array}{l}50.21 \\
50.16\end{array}$ & 50.19 \\
\hline
\end{tabular}

\section{SUMMARY}

Representative volumetric, gravimetric, and electrolytic determinations, many on "practical" samples of alloys or minerals, have been applied on a semimicro level. The use of classical microchemical apparatus, which is usually designed to accomodate only a single sample, has been avoided as far as possible. The timerequirements for practical inorganic analyses involving two to six samples of 20 to $60 \mathrm{mg}$ size are us ually only two-thirds to one-quarter of the requirement for comparable macro-scale determinations. The precision and accuracy of work at the semimicro level compare favorably with that expected in conventional pratice.

\section{RESUME}

Plusieurs méthodes, volumétriques, gravimétriques et ćlectrolytiques, ont été appliquées à l'échelle scmimicro et pour la plupart. à des alliages uu à des minerais. L'utilisation de microappareils pour l'analyse d'un seul échantillon a été évitée autant que possible. Le temps nécessaire pour ces dosages de 2 à 6 échantillons, de 20 à $60 \mathrm{mg}$ est en général réduit aux $2 / 3$ ou au $\mathrm{I} / 4$ du temps nécessairc pour les analyses ordinaires. La précision de ces méthodes est satisfaisante et comparable à celle des méthodes classiques.

Relerences p. 54 . 


\section{ZUSAMMENEASSUNG}

Mit verschiedenen volumetrischen, gravimetrischen und elektrolytischen Methoden wurden Semimikrobestimmungen, grösstenteils mit Proben von Legierungen oder Mineralen, ausgefuhrt. Die Anwendung der klassischen mikrochemischen Apparate, welche meistens für die Bestimmung einer einzigen Probe konstruiert sind, wurde so weit wie möglich vermieden. Solche Bestimmungen von 2 bis 6 Proben von jo 20 bis $60 \mathrm{mg}$ dauern im allgemeinen $2 / 3$ bis $1 / 4$ der Zeit, die für gewöhnliche Analysen benotigt wird. Die Genauigkeit dieser Methoden ist befriedigend und mit derjenigen der klassischen Methoden vergleichbar.

\section{REFERENCES}

1 L. T. HaItett in N. H. Furman Scott's Standard Methods of Chomical Analysis, vol. II, ed. 5, D. Van Nostrand, New York (1939) p. 2460.

- F. HEChT AND J. DoNAU, Anorganische Mikrogewichtsanalyse, Springer, Wien (1940).

- A. A. Bentedti-PichLer, Microtechnique of Inorganic Analysis, Wiley, New York (1942).

- B. I. Clark and H. W. Hermance, J. Am. Chem. Soc., 54 (1932) 877.

- G. H. Walden, L. P. Hammett ANd S. M. EDmonds, J. Am. Chem. Soc., 56 (r934) 350.

- G. IngRam and W. A. Waters in R. F. Milton and W. A. Waters Mothods of Quantitativo Micro-Analysis, Arnold, London (1949).

- E. R. CAlEY AND M. G. BúRFORD, Ind. Eng. Chem., Anal. Ed., 8 (1936) 114.

- W. M. MACNEVIN AND R. H. BouRNigue, Ind. Eng. Chem., Anal. Ed., I5 (r943) 759. 